D.O. Volontsevich, E.A. Veretennikov, I.V. Kostianik, A.S. Iaremchenko, A.I. Efremova, V.O. Karpov

\title{
DETERMINATION OF THE ELECTRIC DRIVE POWER FOR LIGHTLY ARMORED CATERPILLAR AND WHEELED VEHICLES USING SINGLE- OR TWO-STAGE MECHANICAL GEARBOXES
}

When designing electromechanical transmissions (EMT) for lightly armored caterpillar and wheeled vehicles (LACWV), there is often a problem that the coefficient of adaptability of the traction motor (TM) at the minimum design power is not sufficient to meet the requirements for the power range of the transmission. In the literature, several ways have been worked out to solve this problem, however, there was not found a single algorithm allowing to formalize and step by step pass the process of choosing the most rational structure of the EMT. The purpose_of the proposed work is the formation of scientifically based methodology for evaluating the possibility of using single-stage gearboxes in EMT for LACWV and calculation of the required TM power of the selected type for single- or two-stage mechanical gearboxes. Methodology. To carry out the research, the theory of motion of caterpillar and wheeled vehicles was used. Result. A formalized methodology for determining the required mechanical power of the electric drive for the $\mathrm{LACWV}$ is proposed, depending on the power capabilities of the motor-generator set, the torque characteristics of the selected TM and the number of stages in the mechanical gearboxes. Scientific novelty. For the first time, a formalized connection has been established between the tactical and technical requirements for LACWV, the characteristics of the selected TM, the structure and parameters of the mechanical gearboxes. Practical value. The toolkit for the engineering and design personnel developing the EMT for the LACWV was obtained. Work with the algorithm is illustrated by the example of power selection and gear ratios of mechanical gearboxes for the multi-purpose lightly armored caterpillar tractor MT-LB. References 10, tables 3, figures 4 .

Key words: electromechanical transmissions, lightly armored caterpillar and wheeled vehicles, traction electric motor, mechanical gearbox, power transmission range.

При проектуванні електромеханічних трансмісій (ЕМТ) для легкоброньованих гусеничних і колісних машин (ЛБГКМ) часто виникає проблема недостачі коефіцієнта пристосовності тягового електродвигуна (ТЕД) мінімальної розрахункової потужності для задоволення вимогам до силового діапазону трансмісії. У літературі напрацьовано кілька способів рішення цієї проблеми, однак не було знайдено єдиного алгоритму, цио дозволяє формалізувати й покроково провести процес вибору найбільи раціональної структури ЕМТ. Метою запропонованої роботи $\epsilon$ формування науково обтрунтованої методики оцінки можлливості використання одноступінчастих редукторів в ЕМТ для ЛБГКМ і розрахунку необхідної потужності ТЕД обраного типу для одно- або двоступінчастих механічних редукторів. Методика. Для проведення досліджень використовувалися положення теорії руху гусеничних $і$ колісних машин. Результат. Запропонована формалізована методика визначення необхідної механічної потужності електропривода ЛБГКМ залежно від енергетичних можливостей мотор-генераторної установки, моментної характеристики обраних ТЕД і кількості ступенів у механічних редукторах. Наукова новизна. Уперше встановлено формалізований зв'язок між тактико-технічними вимогами до ЛБГКМ, характеристиками обраних ТЕД, структурою і параметрами механічних редукторів. Практична цінність. Отримано інструментарій для інженерноконструкторського персоналу, щц розробляє ЕМТ для ЛБГКМ. Робота з алгоритмом проілюстрована на прикладі вибору потужності $i$ передатних відночень механічних редукторів для багатоцільового легкоброньованого транспортера тягача МТ-ЛБ. Бібл. 10, табл. 3, рис. 4.

Ключові слова: електромеханічні трансмісії, легкоброньовані гусеничні і колісні машини, тяговий електродвигун, механічний редуктор, силовий діапазон трансмісії.

При проектировании электромеханических трансмиссий (ЭМТ) для легкобронированных гусеничных и колесных машин (ЛБГКМ) часто возникает проблема нехватки коэффициента приспособляемости тягового электродвигателя (ТЭД) минимальной расчетной мощности для удовлетворения требованиям к силовому диапазону трансмиссии. В литературе наработано несколько способов решения этой проблемы, однако не было найдено единого алгоритма, позволяющего формализовать и пошагово провести процесс выбора наиболее рациональной структуры ЭМТ. Целью предложенной работы является формирование научно обоснованной методики оценки возможности использования одноступенчатых редукторов в ЭМТ для ЛБГКМ и расчета необходимой мощности ТЭД выбранного типа для одноили двухступенчатых механических редукторов. Методика. Для проведения исследований использовались положения теории движения гусеничных и колесных машин. Результат. Предложена формализованная методика определения необходимой механической мощности электропривода ЛБГКМ в зависимости от энергетических возможностей мотор-генераторной установки, моментной характеристики выбранных ТЭД и количества ступеней в механических редукторах. Научная новизна. Впервые установлена формализованная связь межоу тактико-техническими требованиями к ЛБГКМ, характеристиками выбранных ТЭД, структурой и параметрами механических редукторов. Практическая ценность. Получен инструментарий для инженерно-конструкторского персонала, разрабатывающего ЭМТ для ЛБГКМ. Работа с алгоритмом проиллюстрирована на примере выбора мощности и передаточных отночений механических редукторов для многоцелевого легкобронированного транспортера тягача МТ-ЛБ. Библ. 10 , табл. 3, рис. 4.

Ключевые слова: электромеханические трансмиссии, легкобронированные гусеничные и колесные машины, тяговый электродвигатель, механический редуктор, силовой диапазон трансмиссии.

Introduction. Electromechanical transmissions not only in civilian vehicles, but also in military (EMT) have recently become increasingly widespread, equipment [1-7]. This is due to the fact that EMT can 
provide a number of significant advantages, which were formulated in $[8,9]$ :

- the stepless change of speed, traction force and turning radius;

- ease of automating the transmission and ensuring the control of the vehicle by any crew member and remote control;

- enhanced capabilities for recovering energy from slowing down, turning, oscillations of sprung masses, etc.;

- the possibility of short-term movement without an operating internal combustion engine;

- the possibility of short-term summation of the power of the generator unit and energy storage devices;

- absence of rigid mechanical connections between the main units, facilitating the layout.

Classic stepped mechanical transmissions with hydrodynamic elements almost completely selected their technical potential for increasing the power density and mobility of both tracked (caterpillar) and all-wheel drive wheeled vehicles. In addition, with such transmissions on multi-axle all-wheel vehicles, there is an unjustified complexity in implementing a system for maintaining road holding and thrust control in order to avoid slipping.

All this made the task of designing the EMT for lightly armored caterpillar (tracked) and wheeled vehicles (LACWV) relevant and timely.

Brief analysis of the issue, the goal and definition of the problem. The characteristics of modern traction motors (TMs), in particular induction TMs with frequency control, allow to obtain a hyperbolic characteristic of constant power close to ideal. However, as a rule, it is still not enough to produce an electric drive with stepless regulation in the whole range that is required for vehicles moving not only on paved roads, but also off-road $[8,9]$. This is due to the limitation of the maximum torque of the TM, which is dictated by the value of the maximum current in the windings and overheating.

In existing foreign designs, usually to solve this problem, TMs with large power reserve are used, which cannot even be ensured at all by the total power of the generator and storage device $[2-4,6]$. This leads to an additional increase in the weight, size and cost of such a transmission and reduces in aggregate the advantages that could be obtained when introducing an electric drive for military armored vehicles. In the works $[8,9]$, the traction balance of vehicles with EMT was calculated using the example of the MT-LB tracked multipurpose conveyortractor and the BTR-4 wheeled armored personnel carrier. However, a coherent and relatively universal algorithm that allows determining the limits of the possibility of using single-stage gearboxes in the EMT for the LACWV and the power of the TM required for this purpose has not been found in the scientific literature.

The goal of the work is the formation of a scientifically based methodology for assessing the possibility of using single-stage gearboxes in EMT for LACWVs and calculating the required power of a TM of the selected type for one- or two-stage mechanical gearboxes.

Tasks solved to achieve the goal:

- formalization of requirements for the kinematic and force ranges of EMT for LACWV;
- determination of the required mechanical power of selected TMs for use in transmissions with single-stage mechanical gearboxes while ensuring the specified mobility parameters;

- determination of rational values of transmission ratios of both stages of mechanical gearboxes and the minimum possible value of the required mechanical power of the selected TMs for transmission with twostage mechanical gearboxes.

Algorithm for determining the power and choice of characteristics of the gearbox. According to their functional purpose, LACWVs perform diverse tasks for conducting combat operations in direct contact with the enemy, for transporting personnel, military cargo, towing artillery and other systems both in conditions of paved roads and in full off-road conditions.

If we try to summarize the modern requirements for mobility of these vehicles in relation to electromechanical transmissions, then, first of all, the following should be highlighted:

1) the achievement and long-term maintenance of the maximum speed $v_{\max }$ when driving on the highway;

2) the ability to climb on the soil sodded slope with angle of $\alpha_{\max }$ with speed of at least $v_{\min }$;

$3)$ the acceleration time to maximum speed when driving on the highway;

4) the acceleration time up to speed of $20 \mathrm{~m} / \mathrm{s}$ for wheeled vehicles (WV) and up to $12 \mathrm{~m} / \mathrm{s}$ for caterpillar (tracked) vehicles (CV) when driving on the highway;

5) the acceleration time up to speed of $10 \mathrm{~m} / \mathrm{s}$ when driving on the dry dirt road;

6) the long-term implementation of the dynamic factor $D_{\max }^{L L}$ for $\mathrm{CV}$ and $\mathrm{WV}$ with the power organization of rotation on the principle of $\mathrm{CV}$, as a rule, not less than 0.8 and for WV with kinematic rotation of not less than 0.7 .

The proposed algorithm contains the following sequence of actions:

1. The first requirement allows to determine the minimum required mechanical power of the electric drive, necessary for its implementation. In accordance with $[8,9]$ for the first requirement

$$
N_{v_{\max }}=\frac{\left(G_{M} f+k F v_{\max }^{2}\right) v_{\max }}{\eta_{W G} \eta_{C D}},
$$

where $G_{M}$ is the weight of the vehicle $(\mathrm{N}) ; v_{\max }$ is the maximum speed on the highway $(\mathrm{m} / \mathrm{s}) ; f$ is the coefficient of resistance to movement on the horizontal surface, depending on the quality and microrelief of the terrain and type of propulsion; $k$ is the coefficient of flow around the body of the vehicle $\left(\mathrm{N} \cdot \mathrm{s}^{2} / \mathrm{m}^{4}\right) ; F$ is the area of the frontal projection of the vehicle $\left(\mathrm{m}^{2}\right) ; \eta_{W G}$ is the efficiency of the mechanical wheel gear; $\eta_{C D}$ is the efficiency of the caterpillar propulsion, which at maximum speed is calculated by the formula

$$
\eta_{C D}=a_{1}-a_{2} v_{\max },
$$

where the coefficients $a_{1}$ and $a_{2}$ depend on the type of hinge of the caterpillar propulsion and for the metal hinge (MH) are $a_{1}=0.95$ and $a_{2}=0018 \mathrm{~s} / \mathrm{m}$, and for the rubber metal hinge (RMH) $a_{1}=0.98$ and $a_{2}=0.012 \mathrm{~s} / \mathrm{m}$.

2. According to the calculated power value, the TMs of the adopted type are selected, the total long-term 
operating mechanical power of which is not less than the required value:

$$
N_{\Sigma T M} \geq N_{v_{\max }} .
$$

3. By given or accepted dimensions of the driving wheels $R_{D W}$ and the maximum angular velocity of the TM $\omega_{T M \max }$, we determine the gear ratio of the mechanical wheel gears, allowing the vehicle to move at given maximum speed $v_{\max }$ on the road with hard surface:

$$
i_{W G}=\frac{\omega_{T M \max } R_{D W}}{v_{\max }} .
$$

4. Knowing the value of the gear ratio of the wheel gears and specifying the value of their efficiency depending on the structure, we determine the maximum values of the traction force $P$ and the dynamic factor $D$ of the vehicle at the moment of start at $v=0$ for the shortterm mode and at $v=v_{\min }$ for the long-term mode

$$
\begin{gathered}
P_{v=0}^{A S T}=\frac{M_{\Sigma T M \max }^{A S T} i_{W G} \eta_{W G} \eta_{C D}}{R_{D W}} \text { and } D_{v=0}^{A S T}=\frac{P_{v=0}^{A S T}}{G_{M}} \\
P_{v=v_{\text {min }}}^{L L}=\frac{M_{\Sigma T M \text { max }}^{L L} i_{W G} \eta_{W G} \eta_{C D}}{R_{D W}} \text { and } D_{v=v_{\text {min }}}^{L L}=\frac{P_{v=v_{\text {min }}}^{L L}}{G_{M}},
\end{gathered}
$$

where $M_{\Sigma T M \max }^{A S T}$ is the maximum total short-term allowable torque of all TMs, and $M_{\Sigma T M}^{L L} \max$ is the maximum total long-term torque of all TMs.

5 . We check the value $D_{v=v_{\min }}^{L L}$ for compliance with requirements 6 and 2 at the selected value of the gear ratio of the wheel gear. To do this, we calculate the gear ratio of additional gearboxes

$$
i_{\text {add }}^{D_{\max }}=\frac{D_{\max }^{L L}}{D_{v=v_{\min }}^{L L}} \leq 1 \quad \text { and } \quad i_{\text {add }}^{\alpha}=\frac{f_{\Sigma}}{D_{v=v_{\min }}^{L L}} \leq 1,
$$

where $f_{\Sigma}$ is the total coefficient of resistance to movement, which is determined by the formula

$$
f_{\Sigma}=f \cdot \cos \alpha+\sin \alpha,
$$

where $\alpha$ is the slope angle equal to $\alpha_{\max }-$ the specified in tactical and technical characteristics of the LACWV maximum slope angle on a soil sodded slope.

If one or both conditions are not fulfilled, then it is necessary to take the larger of the values $i_{a d d}^{\alpha}$ and $i_{\text {add }}^{D_{\max }}$ found and, in this number of times by the available method, increase the maximum total long-term operating torque of all TMs or install a reduced stage in the wheel gears with the additional transmission ratio found.

6. Assess the capabilities of the intended power plant, generator and storage devices by the possibilities of long-term and short-term power supply to the transmission.

7. Check the fulfillment of requirements $2-5$ by carrying out a traction calculation in the appropriate road conditions taking into account the limitations on the possibilities of the power plant, generator and storage devices. If, in the course of the calculation, lower stages were introduced in the wheel gears, then the traction calculation should be carried out in two modes - first estimate the acceleration time at the start immediately from the second gear, and then, if conditions are not met, consider acceleration with sequential gears up starting with down one.

We illustrate the above methodology with an example of the development of an electromechanical transmission for the MT-LB multi-purpose conveyor

\begin{tabular}{|c|c|c|}
\hline \multicolumn{2}{|c|}{ Indicator name } & Value \\
\hline \multicolumn{2}{|l|}{ Vehicle weight $G_{M}, \mathrm{~N}$} & 117720 \\
\hline \multicolumn{2}{|l|}{$\begin{array}{l}\text { Maximum velocity on the highway } \\
V_{\max }, \mathrm{m} / \mathrm{s}(\mathrm{km} / \mathrm{h})\end{array}$} & $\begin{array}{l}18.06 \\
(65)\end{array}$ \\
\hline \multirow{2}{*}{$\begin{array}{l}\text { Average velocity of movement, } \\
\mathrm{m} / \mathrm{s}(\mathrm{km} / \mathrm{h})\end{array}$} & \begin{tabular}{|l} 
on the highway \\
$V_{a v}$ \\
\end{tabular} & $\begin{array}{c}11.11 \\
(40)\end{array}$ \\
\hline & \begin{tabular}{|l|} 
on the dirt road \\
$V_{a v}^{*}$
\end{tabular} & $\begin{array}{l}8.33 \\
(30) \\
\end{array}$ \\
\hline \multicolumn{2}{|c|}{ Maximum slope angle on the ground $\alpha_{\max },{ }^{\circ}$} & 35 \\
\hline \multicolumn{2}{|l|}{$\begin{array}{l}\text { Rise velocity with slope } 35^{\circ} \\
\text { not less, } \mathrm{m} / \mathrm{s}(\mathrm{km} / \mathrm{h})\end{array}$} & $1.39(5)$ \\
\hline \multicolumn{2}{|l|}{ Vehicle height $H$, m } & 2.035 \\
\hline \multicolumn{2}{|l|}{ Track width $B, \mathrm{~m}$} & 2.5 \\
\hline \multicolumn{2}{|l|}{ Clearance $h, \mathrm{~m}$} & 0,4 \\
\hline \multicolumn{2}{|l|}{ Driving wheel radius $R_{D W}, \mathrm{~m}$} & 0.265 \\
\hline \multicolumn{2}{|l|}{ Flow rate $k,\left(\mathrm{~N} \cdot \mathrm{s}^{2}\right) / \mathrm{m}^{4}$} & 0.65 \\
\hline \multicolumn{2}{|c|}{$\begin{array}{l}\text { Calculated acceleration time on the highway, } \mathrm{s} \text { (no } \\
\text { more) to velocity } 0.95 v_{\max }-17.153 \mathrm{~m} / \mathrm{s} \\
(61.75 \mathrm{~km} / \mathrm{h})\end{array}$} & 60 \\
\hline \multicolumn{2}{|c|}{$\begin{array}{l}\text { Calculated acceleration time on the highway, s (no } \\
\text { more) to velocity } 11.11 \mathrm{~m} / \mathrm{s}(40 \mathrm{~km} / \mathrm{h})\end{array}$} & 15 \\
\hline \multicolumn{2}{|c|}{$\begin{array}{l}\text { Calculated acceleration time on the dirt road, s (no } \\
\text { more) to velocity } 8.33 \mathrm{~m} / \mathrm{s}(30 \mathrm{~km} / \mathrm{h})\end{array}$} & 10 \\
\hline \multicolumn{2}{|c|}{ Maximum value of the dynamic factor (not less) } & 0.8 \\
\hline
\end{tabular}
tractor.

Initial data for calculations on the vehicle are presented in Table 1, regarding TM - in Table 2.

Table 1

Initial data on the conveyor tractor

Characteristics of the TM M73

\begin{tabular}{|l|c|}
\hline \multicolumn{1}{|c|}{ Indicator } & Value \\
\hline TM mass, $\mathrm{kg}$ & 88 \\
\hline Dimensions (diameter $\times$ length), $\mathrm{mm}$ & $483 \times 232$ \\
\hline TM maximum power, $\mathrm{kW}$ & 150 \\
\hline TM maximum long-term power, $\mathrm{kW}$ & 120 \\
\hline Maximum rotation speed, rpm & 3100 \\
\hline Maximum long-term torque, $\mathrm{Nm}$ & 1050 \\
\hline $\begin{array}{l}\text { Maximum short-term torque } \\
\text { (less than a minute), Nm }\end{array}$ & 2050 \\
\hline
\end{tabular}

In accordance with the proposed algorithm:

1. Power required to reach maximum velocity

$$
\begin{aligned}
& N_{v_{\max }}=\frac{\left(G_{M} f+k F v_{\max }^{2}\right) v_{\max }}{\eta_{W G} \eta_{C D}}= \\
& =\frac{\left(117720 \cdot 0.045+0.65 \cdot 4.0875 \cdot\left(\frac{65}{3.6}\right)^{2}\right) \frac{65}{3.6}}{0.98 \cdot\left(0.95-0.018 \frac{65}{3.6}\right)}=181692 \mathrm{~W},
\end{aligned}
$$


where the frontal area of the vehicle is

$$
F=B(H-h)=2.5(2.035-0.4)=4.0875 \mathrm{~m}^{2} \text {. }
$$

2. For the TM M73, having a long-term power of $120 \mathrm{~kW}$, two TMs will suffice - one for each driving wheel (board). will be

3. The gear ratio of the wheel gears for these TMs

$$
i_{W G}=\frac{\omega_{T M \max } R_{D W}}{v_{\max }}=\frac{\frac{\pi \cdot 3100}{30}}{\frac{65}{3.6}} \cdot 0.265=4.765 .
$$

4. We determine the maximum values of the traction force and the dynamic factor of the vehicle at the moment of start at $v=0$ for the short-term mode and at $v=v_{\min }$ for the long-term mode:

$$
\begin{gathered}
P_{v=0}^{A S T}=\frac{M_{\Sigma T M \max }^{A S T} i_{W G} \eta_{W G} \eta_{C D}}{R_{D W}}= \\
=\frac{2 \cdot 2050 \cdot 4.765 \cdot 0.98 \cdot 0.95}{0.265}=68636 \mathrm{~N} ; \\
D_{v=0}^{A S T}=\frac{P_{v=0}^{A S T}}{G_{M}}=\frac{68636}{117720}=0.583 ; \\
=\frac{M_{\Sigma=v_{\min }}^{L L}=\frac{i^{L L} i_{W G} \eta_{W G} \eta_{C D}}{R_{D W}}=}{2 \cdot 1050 \cdot 4.765 \cdot 0.98 \cdot\left(0.95-0.018 \frac{5}{3.6}\right)}=34230 \mathrm{~N} ; \\
0.265 \\
D_{v=v_{\min }}^{L L}=\frac{P_{v=v_{\min }}^{L L}}{G_{M}}=\frac{34230}{117720}=0.291 .
\end{gathered}
$$

5. We calculate the gear ratios of additional gearboxes:

$$
\begin{gathered}
i_{\text {add }}^{D_{\max }}=\frac{D_{\max }^{L L}}{D_{v=v_{\min }}^{L L}}=\frac{0.8}{0.291}=2.75>1 ; \\
i_{a d d}^{\alpha}=\frac{f_{\Sigma}}{D_{v=v_{\min }}^{L L}}=\frac{0.065 \cdot \cos 35^{\circ}+\sin 35^{\circ}}{0.291}=2.154>1 .
\end{gathered}
$$

The values obtained indicate that in this configuration, the electromechanical drive for the conveyor tractor will not meet the requirements of either point 2 or point 6 .

6. To solve this problem, it is necessary either to increase by 2.75 times the total torque at the TM, or to introduce an additional reduced stage in the wheel gears with an additional gear ratio of 2.75 .

Consider the first solution of the issue.

The increase in the total long-term TM torque is possible either by switching to a higher torque TM or increasing their number. In our case, there is only an opportunity to apply a larger number of TMs M73 accepted for calculation.

We estimate the power that will be consumed by 6 TMs M73 when implementing $D_{v=v_{\min }}^{L L}=0.8$. In this case, the traction force should be

$$
P_{v=v_{\text {min }}}^{L L}=D_{v=v_{\text {min }}}^{L L} G_{M}=0.8 \cdot 117720=94176 \mathrm{~N} \text {. }
$$

Accordingly, the total torque of all six TMs will be

$$
\begin{aligned}
& M_{\Sigma T M \max }^{L L}=\frac{P_{v=v_{\min }}^{L L} R_{D W}}{i_{W G} \eta_{W G} \eta_{C D}}= \\
& =\frac{94176 \cdot 0.265}{4.765 \cdot 0.98 \cdot\left(0.95-0.018 \frac{5}{3.6}\right)}=5778 \mathrm{Nm} .
\end{aligned}
$$

Their rotation speed will be

$$
\omega_{T M}=\frac{v_{\min } i_{W G}}{R_{D W}}=\frac{\frac{5}{3.6} \cdot 4.765}{0.265}=24.97 \mathrm{~s}^{-1} .
$$

The mechanical power consumed will be just

$$
N_{D \text { max }}=\omega_{T M} M_{\Sigma T M \text { max }}^{L L}=24.97 \cdot 5778=144299 \mathrm{~W} \text {, }
$$
which is completely valid.

We consider the second solution.

In this case, we leave two TMs M73 and add a lower stage in the wheel gears with gear ratio

$$
i_{L}=i_{W G} \cdot i_{\text {add }}^{D_{\max }}=4.765 \cdot 2.75=13.1 .
$$

7. Let us check the fulfillment of requirements $2-5$ for both options by carrying out traction calculation in appropriate road conditions taking into account the limitations on the possibilities of the power plant, generator and storage devices. We take the maximum total long-term mechanical power of all six TMs M73 equal to $200 \mathrm{~kW}$.

Then the dependence of the total torque of all $6 \mathrm{TMs}$ on the rotation speed of the armature will correspond to the curve shown in Fig. 1. And, respectively, the graph of the dynamic factor for a vehicle with 6 TMs M73, calculated by the formula

$$
D=\frac{\frac{M_{\Sigma T M}^{L L} i_{W G} \eta_{W G} \eta_{C D}}{R_{D W}}-k F v^{2}}{G_{M}},
$$

will have the form shown in Fig. 2.

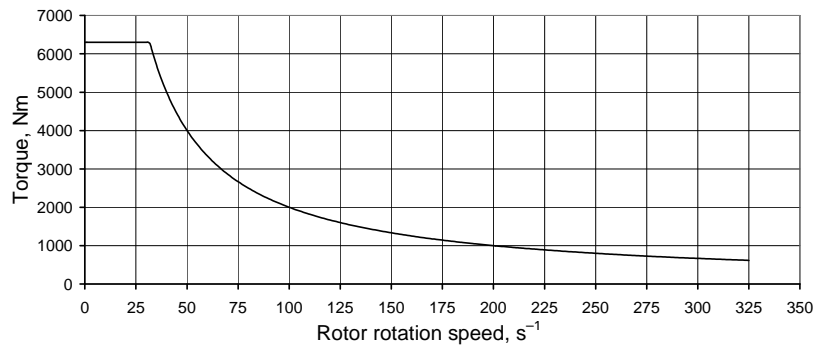

Fig. 1. Total torque of $6 \mathrm{TMs}$ M73 at power limit $200 \mathrm{~kW}$

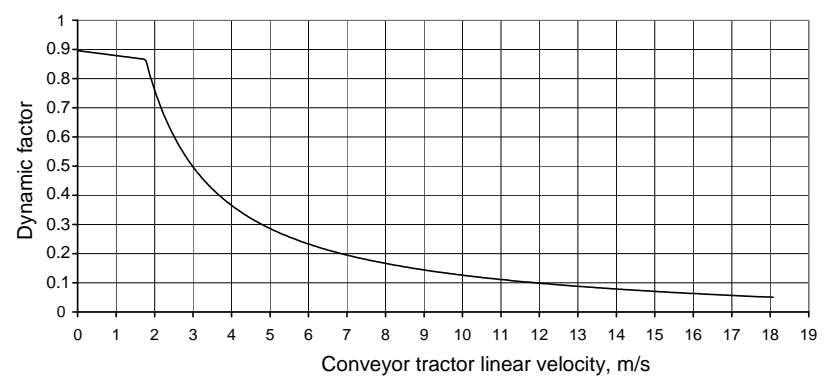

Fig. 2. Dynamic factor of the conveyor tractor with 6 TMs M73 at power limit $200 \mathrm{~kW}$

Respectively, for two TMs M73 and two-stage wheel gear, graphs of the total torque and dynamic factor are presented in Fig. 3, 4. 


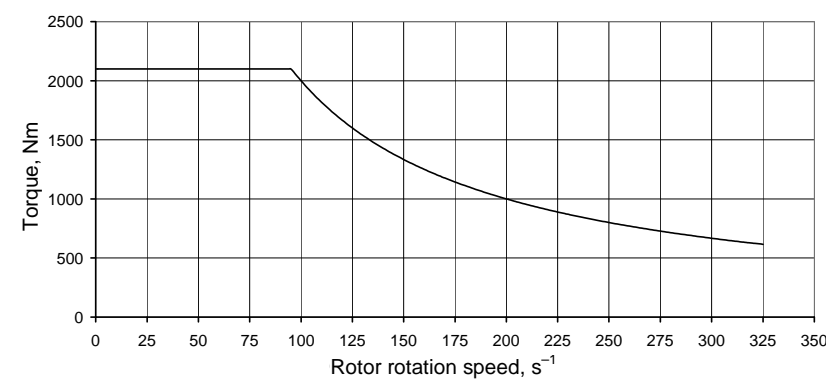

Fig. 3. Total torque of $2 \mathrm{TMs}$ M73 at power limit $200 \mathrm{~kW}$

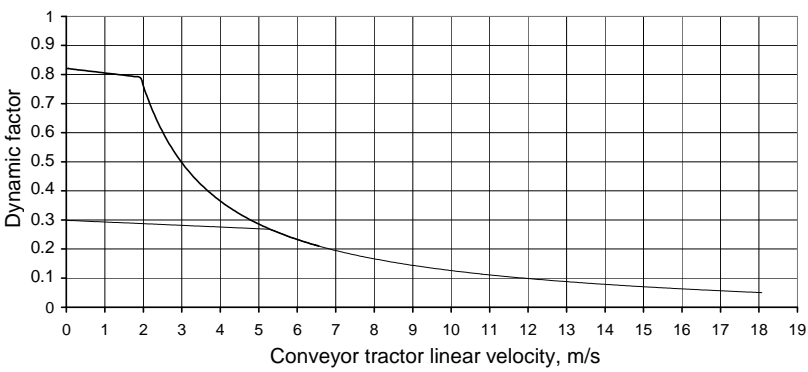

Fig. 4. Dynamic factor of the conveyor tractor with 2 TMs M73 at power limit $200 \mathrm{~kW}$

To verify the requirements of $2-5,3$ variants of calculations were carried out for the vehicle accelerating on a horizontal surface:

- 6 TMs M73, single-stage wheel gears with $i_{W G}=$ $=4.765$;

- 2 TMs M73, two-stage wheel gears with gear ratios - reduced $i_{L}=13.1$ and normal $i_{W G}=4.765$, acceleration from the transmission of the normal series without switching in the process of movement;

- 2 TMs M73, two-stage wheel gears with gear ratios - reduced $i_{L}=13.1$ and normal $i_{W G}=4.765$, acceleration from the lower stage with switching during movement.

Also, calculations were carried out to determine the maximum velocity of the vehicle to climb $35^{\circ}$ on the dirt road in two versions:
- 6 TMs M73, single-stage wheel gears with $i_{W G}=$ $=4.765$.

- 2 TMs M73, two-stage wheel gears with gear ratios - reduced $i_{L}=13.1$ and normal $i_{W G}=4.765$, acceleration and movement in low gear.

The results of the calculations are given in Table 3 .

Analysis of the results obtained. The variant of construction of the EMT for the MT-LB conveyor tractor with two TMs M73 and single-stage wheel gears was removed from consideration as not allowing to provide for points 2 and 6 of the «Requirements».

The remaining three options for construction suggest:

- six TMs M73 (three per board) with two single-stage wheel gears (one per board);

- two TMs M73 (one per board) with two two-stage wheel gears (one per board) with the possibility of activating a lower row when stopping the vehicle to drive in heavy road conditions;

- two TMs M73 (one per board) with two two-stage wheel gears (one per board) with the possibility of sequential activation of the reduced and normal rows in motion, both during acceleration and deceleration.

The requirements for mobility of LACWV, prescribed in $[1,2]$, are underestimated and, in fact, repeat the parameters of a vehicle with a classic mechanical manual transmission. All three retained for consideration options for building EMT confidently meet the requirements.

The best performance of the mobility of the conveyor tractor has EMT, consisting of six TMs M73 (three TMs per board) with two single-stage wheel gears (one per board). However, its use leads to an increase in the drive mass by $352 \mathrm{~kg}$ and cost - at the cost of four additional TMs M73 compared to a transmission containing 2 TMs M73 and 2 single-stage wheel gears.

Results of calculations of the mobility of the conveyor tractor at power limit of $200 \mathrm{~kW}$

Table 3

\begin{tabular}{|c|c|c|c|c|c|c|c|}
\hline \multirow{3}{*}{ Indicator name } & \multirow{3}{*}{ Requirement } & \multirow{2}{*}{\multicolumn{2}{|c|}{6 TMs M73 }} & \multicolumn{4}{|c|}{2 TMs M73 } \\
\hline & & & & \multicolumn{2}{|c|}{$\begin{array}{c}\text { Acceleration in the } \\
\text { normal row }\end{array}$} & \multicolumn{2}{|c|}{$\begin{array}{l}\text { Acceleration with } \\
\text { switching }\end{array}$} \\
\hline & & MH & $\mathrm{RMH}$ & MH & $\mathrm{RMH}$ & MH & RMH \\
\hline $\begin{array}{l}\text { Rise velocity with slope } 35^{\circ} \\
\text { not less, } \mathrm{m} / \mathrm{s}(\mathrm{km} / \mathrm{h})\end{array}$ & $1.389(5)$ & $\begin{array}{l}2.408 \\
(8.67)\end{array}$ & $\begin{array}{l}2.522 \\
(9.08)\end{array}$ & - & - & $\begin{array}{l}2.408 \\
(8.67)\end{array}$ & $\begin{array}{l}2.522 \\
(9.08)\end{array}$ \\
\hline \multirow{2}{*}{$\begin{array}{l}\text { Calculated acceleration time on the highway, s (no } \\
\text { more) to velocity } 0.95 v_{\max }-17.153 \mathrm{~m} / \mathrm{s} \\
(61.75 \mathrm{~km} / \mathrm{h})\end{array}$} & \multirow[b]{2}{*}{60} & 29.622 & 20.335 & 30.64 & 21.286 & 29.629 & 20.341 \\
\hline & & $100 \%$ & $100 \%$ & $-3.4 \%$ & $-4.7 \%$ & $-0.02 \%$ & $-0.03 \%$ \\
\hline \multirow{2}{*}{$\begin{array}{l}\text { Calculated acceleration time on the highway, s (no } \\
\text { more) to velocity } 12 \mathrm{~m} / \mathrm{s}(43.2 \mathrm{~km} / \mathrm{h})\end{array}$} & \multirow{2}{*}{15} & 8.153 & 7.063 & 9.17 & 8.014 & 8.159 & 7.069 \\
\hline & & $100 \%$ & $100 \%$ & $-12.5 \%$ & $-13.5 \%$ & $-0.07 \%$ & $-0.08 \%$ \\
\hline \multirow{2}{*}{$\begin{array}{l}\text { Calculated acceleration time on the dirt road, } \mathrm{s} \text { (no } \\
\text { more) to velocity } 10 \mathrm{~m} / \mathrm{s}(36 \mathrm{~km} / \mathrm{h})\end{array}$} & \multirow{2}{*}{10} & 5.879 & 5.141 & 7.064 & 6.245 & 5.884 & 5.147 \\
\hline & & $100 \%$ & $100 \%$ & $-20.2 \%$ & $-21.5 \%$ & $-0.09 \%$ & $-0.12 \%$ \\
\hline \multirow{2}{*}{$\begin{array}{l}\text { Maximum long-term value of the dynamic factor } \\
\text { (not less) }\end{array}$} & \multirow{2}{*}{0.8} & 0.896 & 0.924 & 0.299 & 0.308 & 0.821 & 0.847 \\
\hline & & $100 \%$ & $100 \%$ & - & - & $-8.37 \%$ & $-8.33 \%$ \\
\hline
\end{tabular}

The smallest weight and cost when losing the first option in mobility from $3 \%$ to $21.5 \%$, depending on the indicator and the type of hinge of the tracked propulsion, has the option with two TMs M73 and two two-stage wheel gears with the ability to turn on the reduced row when stopping the vehicle for movement only at heavy road conditions. In this case, it is possible to avoid friction discs in a two-stage planetary gearbox, and to organize switching by means of gear couplings by analogy with the reversing onboard gear of the fighting 
vehicle «Oplot». In contrast to the first option, an increase in the mass of the drive is expected to be in the range of only $160-165 \mathrm{~kg}$ compared to a transmission containing 2 TMs M73 and 2 single-stage wheel gears.

The most promising, in our opinion, is the third option, which very slightly loses to the first option in mobility (from $0.02 \%$ to $8.37 \%$ ), but in the case of a properly designed wheel gear, it is possible to combine the functions of stopping brakes and control range switching clutches on the same friction devices. In this case, weight increase is expected to $200 \mathrm{~kg}$.

\section{Conclusions and recommendations.}

As a result of the presented work, a scientifically based method was developed, which allows to find the required power of the TM of the selected type when using single- or two-stage mechanical gearboxes.

The obtained method allows the developer of an electromechanical transmission to determine rational limits for using single-stage mechanical gearboxes and, if necessary, to choose a method for using two-stage mechanical gearboxes sufficient to provide the specified tactical and technical characteristics of military equipment.

\section{REFERENCES}

1. Walentynowicz Je. Hybrid and electric power drive combat vehicles. Journal of KONES Powertrain and Transport, 2011, vol.18, no.1, pp. 471-478.

2. Colyer Ron E. The use of electric and hybrid-electric drives in military combat vehicles. Journal of Battlefield Technology, 2003, vol.6, no.3, pp. 11-15.

3. All Electric Combat Vehicles (AECV) for Future Applications / Report of the Research and Technology Organization (RTO) of NATO Applied Vehicle Technology Panel (AVT) Task Group AVT-047 (WG-015). 2004. 234 p.

4. Galvagno E., Rondinelli E., Velardocchia M. Electromechanical transmission modelling for series-hybrid tracked tanks. International Journal of Heavy Vehicle Systems, 2012, vol.19, no.3, pp. 256-280. doi: 10.1504/ijhvs.2012.047916.

5. Glebov V.V., Klimov V.F., Volosnikov S.A. Assessment of the Possibility to Use Hybrid Electromechanical Transmission in
Combat Tracked Platforms. Mechanics, Materials Science \& Engineering, 2017, vol.8, pp. 99-105. doi: 10.2412/mmse.83.5.981.

6. Erkhart P. Elektrische Kraftübertragung - Technologie und praktische Anwendung. Soldat und Technik, 2003. pp. 22-27. (Ger).

7. Ilijevski Ž. A Hybrid-Electric Drive Concept For High Speed Tracked Vehicles. Brodarski Institut, Zagreb, Croatia. 2006. 9 p.

8. Sivakumar P., Reginald R., Venkatesan G., Viswanath H., Selvathai T. Configuration Study of Hybrid Electric Power Pack for Tracked Combat Vehicles. Defence Science Journal, 2017, vol.67, no.4, pp. 354-359. doi: 10.14429/dsj.67.11454.

9. Volontsevich D.O., Veretennikov E.A., Yefremova A.I., Yaremchenko A.S., Prokop'ev M.I. Traction balance for perspective tracked multipurpose carrier-truck with electromechanical transmission is located on the sides. Bulletin of NTU «KhPI». Series: Transport machine building, 2017, no.5(1227), pp. 162-167. (Rus).

10. Volontsevich D.O., Veretennikov E.A., Mormilo Ya.M., Yaremchenko A.S., Karpov V.O. Traction balance for perspective wheeled armored personnel carrier with electromechanical transmission. Bulletin of NTU «KhPI». Series: Transport machine building, 2017, no.5(1227), pp. 168-173. (Rus).

Received 27.08.2018

D.O. Volontsevich ${ }^{1}$, Doctor of Technical Science, Professor,

E.A. Veretennikov ${ }^{1}$, Candidate of Technical Science,

I.V. Kostianik ${ }^{1}$, Candidate of Technical Science, Associate

Professor,

A.S. Iaremchenko ${ }^{1}$, Postgraduate Student,

A.I. Efremova ${ }^{1}$, Postgraduate Student,

V.O. Karpov ${ }^{1}$, Postgraduate Student,

${ }^{1}$ National Technical University «Kharkiv Polytechnic Institute», 2, Kyrpychova Str., Kharkiv, 61002, Ukraine, phone +380 577076355 ,

e-mail: vdo_khpi@ukr.net

\section{How to cite this article:}

Volontsevich D.O., Veretennikov E.A., Kostianik I.V., Iaremchenko A.S., Efremova A.I., Karpov V.O. Determination of the electric drive power for lightly armored caterpillar and wheeled vehicles using single- or two-stage mechanical gearboxes. Electrical engineering \& electromechanics, 2019, no.1, pp. 29-34. doi: 10.20998/2074-272X.2019.1.05. 